\title{
After the Trade Dispute: Is Indonesian Food Sovereignty Threatened?
}

\author{
Kadek Sarna* \\ Doctoral Program (S3) at the Faculty of Law, \\ Gadjah Mada University, Yogyakarta \\ Nurhasan Ismail ${ }^{* *}$ \\ Department of Agrarian Law at the Faculty of Law, \\ Gadjah Mada University, Yogyakarta \\ Harry Supriyono ${ }^{* * *}$ \\ Department of Environmental Law at the Faculty of Law, \\ Gadjah Mada University, Yogyakarta
}

Article Received: $7^{\text {th }}$ February 2020; Accepted: 22 ${ }^{\text {nd }}$ July 2020; Published: $3^{\text {th }}$ July 2020

\begin{abstract}
The winning of New Zealand and the United States in a trade dispute with Indonesia regarding quantitative restrictions on the import of horticultural products, animals and animal products at the World Trade Organization (WTO) dispute panel assembly with case number DS (Dispute Settlement) 477 and 478, forces Indonesia to adjust its national policies with the existing rules in the 1994 GATT. This obviously becomes a concern for Indonesia's goal of realizing national food security and food sovereignty. This article aims to discuss how Indonesia's position in the case of DS 477 and DS 478 and how policy efforts in agriculture can be implemented so that Indonesia can withstand the development of international trade liberalization. This article is normative legal research that applies case and statutory approaches. It discusses the legal position of Indonesia when defending its reasons behind the restriction policies as well as analyses Indonesia's opportunities to create food sovereignty and proposing legitimate policies after the cases decided. This article concludes that despite Indonesia was defeated in these cases, the opportunities for Indonesian agricultural products to be internationally marketed are still available and that bilateral arrangement would enable Indonesia to discuss the upcoming legitimate measures to be adopted. Reflecting on the results of WTO DS 477 and DS 478 cases, Indonesia should propose a Mutually Agreed Solution (MAS) and improving the provisions on horticulture imports and imports of animal products, carry out intensification and extensification policy, combat food cartels, and pay concern on the creation and implementation of various international trade regulations.
\end{abstract}

Keywords: Food Sovereignty; Trade Dispute; Indonesia; World Trade Organization.

\footnotetext{
“Email/Corresponding Author: sarna.kadek@gmail.com / kadek_sarna@unud.ac.id / kadek.sarna@ugm.ac.id

** Email : nurhasan@mail.ugm.ac.id

***Email: harry.supriyono@ugm.ac.id
} 
How to cite: Sarna, Kadek, Nurhasan Ismail and Harry Supriyono. "After the Trade Dispute: Is Indonesian Food Sovereignty Threatened?". Udayana Journal of Law and Culture 4, no. 2 (2020): 171-192. https://doi.org/10.24843/UJLC.2020.v04.i02.p03

doi: https://doi.org/10.24843/UJLC.2020.v04.i02.p03

\section{Introduction}

The Indonesian Constitution stipulates that one of the purposes of the State of the Republic of Indonesia is to promote public welfare. ${ }^{1}$ It means that the state has an important role in realizing welfare through the fulfillment of basic rights, one of which is the right to food as a fundamental human right for all citizens without exception.

In the context of creating prosperity, agriculture has become an important sector, because the Indonesian population mostly depends on this sector for their main livelihood. Due to the strong relationship between the Indonesian people and agricultural life, agriculture does not only have economic value but also social and religious values so that aside from being an archipelagic maritime country, Indonesia is also known as the largest agricultural country. For more than a decade, the government paid more attention to the sector of agriculture and tends to achieve prosperity and food security. ${ }^{2}$

Up to now, the government is still dealing with the decreasing number of agricultural lands due to land conversion, the competitiveness of agricultural products, and other matters to be resolved. It indeed threatens food security. The government seems to do not have any other choice rather than to import some food products to secure their domestic needs. Therefore, the national policy in controlling the functional shift of the agricultural land through the protection of sustainable agricultural land, and improvement of the quality and quantity of agriculture products are urgent to be applied.

Establishing food security and sovereignty through the protection of agricultural land is also an inseparable effort from reforming the current national agrarian policy. It has been conceptualized that agrarian reform is an absolute requirement to holistically restructuring the aspects of ownership, as well as aspects of land use and utilization, ${ }^{3}$ which should be synergized with efforts to revitalize agriculture sector.

1 The 1945 Constitution of the Republic of Indonesia, Preamble, para 4.

2 See for example the enactment of Law No.41 of 2009 concerning the Protection of Sustainable Agricultural Land as well as several other laws and regulations such as Law No.13 of 2010 concerning Horticulture, Law No.18 of 2012 concerning Food, Regulation of the Minister of Agriculture No.86/Permentan/OT.140/8/2013 concerning the Import Recommendation of Horticultural Products, and other related regulations.

${ }^{3}$ See Article 2 of the Decree of the People's Consultative Assembly of the Republic of Indonesia concerning Agrarian Reform and Management of Natural Resources 
The biggest challenge that facing Indonesia today as a developing country to create food security and sovereignty, is a multiplier effect of world trade liberalization and globalization that occurred in the last few decades where liberalization of trade and investment has become a world trend so that the boundary between developed and developing countries have no effect anymore and have even influenced internal policies and political traditions of the state that are within them. Reflecting on those developments, Thomas L. Friedman has given an illustration that the world is currently experiencing a struggle between realizing development and prosperity which is symbolized by the lexus and the desire to maintain an identity and tradition symbolized by olive trees. This parable also means that there is a conflict of values in globalization brought by the world trade liberalization regime, where the policies and political freedoms of a country who involved will be bound by global political interests. ${ }^{4}$

Globalization and world trade liberalization are difficult to avoid. It always metamorphoses following human needs and desires as well as looks for loopholes in human systems. Peter Van Den Bossche said:

"Three reasons come to mind. First, new technology has created distribution channels, especially for services,..... will find very difficult to control. Secondly, liberal international trade policies ... firm institutional basis in the multilateral trading system of the WTO,......Thirdly, the price to be paid,.......withdrawing from the global economy would be very high. ${ }^{5}$

Bossche's description above implies that economic globalization which is synonymous with technological development is a difficult process to control while the liberal policy of international trade driven by the World Trade Organization (WTO) has taken root in every multilateral trade relationship. Besides, it explains huge costs are required to create prosperity when withdrawing from the development of the global economy.

The current development of food globalization appears to be metamorphosed, following technological developments of the industry. The penetration of food products through marketing networks and efficient distribution has opened cross-border barriers to global trade. In Indonesia, food globalization can be seen from the increased import of agricultural food products such as rice, fresh fruit, fresh vegetables from Vietnam, Thailand, the United States, New Zealand, Australia, and the Peoples' Republic of China. Hundreds of processed food products have also entered many hypermarkets and traditional markets. This is what later became one of the

${ }^{4}$ See Thomas L. Friedman, The Lexus and the Olive Tree: Understanding Globalization, $2^{\text {nd }}$ edition (New York: First Anchor Books, 2000), 67-68.

5 Peter Van den Bossche. The Law and Policy of The World Trade Organization: Text, Cases, and Materials, 2nd edition (New York: Cambridge University Press, 2008), 5. 
factors that made our food sovereignty disrupted and experienced challenges.

Budi Widianarko said that globalization is always associated with the terms principles of liberalization and harmonization. Food globalization as one of its sub-systems is also subject to these two principles, liberalization manifested in the form of market openness, in which western countries urge developing countries to follow and adopt free trade, including for agriculture and food, while the principle of harmonization is manifested in the form of uniformity quality and safety standards for food products that have been going on intensely. He mentioned one of the main clauses of the Agreement on Agriculture (Agreement on Agriculture-AoA) in the 1994 GATT framework or known as the agreement on sanitary and phytosanitary (the SPS agreement) in the WTO regime which stated "harmonization of sanitary and phytosanitary measures based on accepted and scientifically justifiable standards ". Although the agreement is in the name of consumers all over the world, it still reflects the victory of the lobby of developed countries over developing countries because the principle of harmonization is often a barrier to exports of food products in developing countries because of gaps in know-how and equipment, in which products from developed countries are free to enter the markets developing country. ${ }^{6}$

The WTO stimulates global free and fair trade. In performing its duties, it applies several principles that become binding rules for all members such as the principle of protection through tariffs, the national treatment principle, the most favored nations principle, the principle of reciprocity, and the principle of quantitative border restrictions. In practice, however, free trade does not completely free and fair. Countries that are classified as developing and least-developed face some difficulties in competing developed countries. ${ }^{7}$ This often causes disputes between WTO members, especially for developing countries over their actions or policies that seek to protect their domestic industries by minimizing the negative impact of imports, such as Indonesia in the case of WTO DS 477 and DS 478.

In the WTO cases DS 477 and DS 478, Indonesia's food sovereignty experienced a shock where since 2012 there has been a trade dispute between Indonesia, New Zealand and the United States regarding restrictions on imports of horticultural products, animals and animal products, wherein 2014 the two countries (the US and New Zealand) finally brought this dispute to the WTO dispute panel.

\footnotetext{
"Budi Widianarko. Globalisasi Pangan "Masih adalah Peluang bagi Pertanian Indonesia" dalam Revitalisasi Pertanian dan Dialog Peradaban. (Jakarta : Kompas, 2006), 166-167.

${ }^{7}$ M. Ya'kub Aiyub Kadir, The World Trade Organization (WTO) Free Trade Within Fair Trade Challenges, Mimbar Hukum 26, No.1(2014): 133.
} 
This article is normative legal research that applies case and statutory approaches. It discusses the legal position of Indonesia regarding restrictions on imports of horticultural products, animals, and animal products on the case of DS 477 and DS 478. Besides, it analyses Indonesia's opportunities to create food sovereignty and proposing legitimate policies after WTO DS 477 and DS 478 cases to ensure international market availability for its agricultural products.

\section{Result and Discussion/Analysis}

\subsection{Indonesia's Position regarding Restrictions on Imports of Horticultural Products, Animals and Animal Products in the WTO DS477 and DS478 Cases}

Before discussing the case on the importation of agricultural products, animals and animal products which experienced by Indonesia at the WTO or known as the Dispute Settlement 477 (New Zealand) and the Dispute Settlement 478 (United States), we need to consider a flashback on Indonesia's membership in international trade agency from the era of GATT up to WTO.

Based on the Agreement Establishing the World Trade Organization, Membership in GATT can be carried out through 3 (three) methods which include:

a) Original member 8 , is the original membership as a party participating in the negotiations when negotiations are held to formulate GATT agreement;

b) Accession, is membership based on the provisions of GATT 1947 article XXXIII';

c) Sponsorship (succession) is membership of a colony of a country which is an original member who then obtains his independence.

Indonesia entered into the GATT in 1950 through the sponsorship category based on the provisions of GATT 1947 Article XXVI paragraph 5 (c) ${ }^{10}$, because as a condition to take the path (a) and (b) the prospective member country must first negotiate tariffs, whereas when GATT was ratified in 1947 , Indonesia as a newly born country and was still facing an upheaval of independence so factually did not participate in signing the "Protocol of Provisional Application" (PPA) as a sign of the GATT enactment. Furthermore, with the ratification of the WTO Agreement by Indonesia into Law Number 7 of 1994 dated November 2, 1994, concerning ratification of the "Agreement

\footnotetext{
8 The term original member is found in Article XI of the WTO Agreement, and this term is used to distinguish between original members and new members. Relating subject also see Peter Van Den Bossche, The Law and Policy of the World Trade Organization-Text Cases and Materials, 2nd edition (New York: Cambridge University Press, 2008), 108

9 See Article XXXIII of GATT.

10 See Article XXVI paragraph 5 (c) of GATT.
} 
Establishing the World Trade Organization", Indonesia's membership in the GATT-WTO became legally binding on its national policies and legislation.

On its development related to the Doha Development Agenda (DDA), the Ministerial Conference as the highest body in the WTO, in 2001 held a round of negotiations with the aim is to form a multilateral trade system within a development dimension, where the main issues discussed covering agricultural issues, product market access Non-Agricultural Market (NAME), trade in services, and regulation of the Rules. Ministerial Conference is conducted every two years where decision making based on consensus by all member countries. The activities of decision making are carried out by the General Council assisted by the subsidiary body including councils, committees, and sub-committees who have a task to implementing and supervise the implementation of WTO agreements by its member countries.

The issue of agriculture and agricultural product in WTO are sometimes discussed through a series of negotiation especially related to the reduction in domestic subsidies and tariffs. Indonesia and other developing countries pay serious attention to the agriculture issue as it is related to socio-economic aspects such as food security, livelihood security, and rural development, which they face at all times. On the contrary, developed countries see the provision of domestic subsidies from a political dimension in their agricultural policies such as market domination for economic purposes. Various attempts have been made during the negotiation process, until a "suspension" was imposed in June 2006, which was then followed by full negotiations in early February 2007. In July 2008, ministerial-level negotiations were also conducted to jointly conclude agricultural modalities and NAMAs, and using single-undertaking issues such as trade in services, intellectual property, development, and dispute resolution, but all of these efforts have not shown results as expected. ${ }^{11}$

During the WTO $9^{\text {th }}$ Ministerial Conference held in Bali on 3-7 December 2013, the WTO members agreed on "the Bali Package" that among others established the Trade Facilitation Agreement which aims to facilitate the flow of goods at ports to in and out of the countries. The smooth flow of goods at the port will be able to support Indonesia's efforts in increasing economic competitiveness and market access for Indonesian export products. Besides, the Bali Package (Post Bali Work) also agreed on flexibility in the issue of public stockholding for food security that gives freedom to developing countries like Indonesia, to providing subsidies to create the availability of cheap food for the whole citizens, without worrying

${ }^{11}$ See more information on Robert Wolfe, "Sprinting during a Marathon: Why the WTO Ministerial Failed in July 2008," Journal of World Trade 44, No. 1 (2010): 81-126 and YongShik Lee, "International Trade Law Post Neoliberalism," Buffalo Law Review 68 no.2 (2020): 434-436 
being sued in the WTO Dispute forum Settlement Body. ${ }^{12}$ In the Post Bali Work, member countries were asked to arrange a Doha Development Agenda (DDA) settlement work program in 2014. With the completion of the DDA negotiations, it is expected to benefit developing countries and the Least Developed Countries (LDCs) ${ }^{13}$ in integrating into the trading system multilateral.

Indonesia's position was then questioned in the international traffic of trade in horticultural products, animals and animal products. Before the $9^{\text {th }}$ Ministerial Conference held in Bali on 3 - 7 December 2013 was held, Indonesia has been in a trade dispute with the US and New Zealand related to Indonesian policies in horticultural products, animals and animal products with the existing policies in WTO. Indonesian Ministry of Trade has several times held consultative efforts with New Zealand and the United States (US) and in February and September 2013. On one hand, New Zealand and the US argued that Indonesian policies were hampering access to their market and violate the WTO provisions, but on the other hand, Indonesia considers its policies have complied with the provisions in the WTO.

The existence of two different views and the absence of a solution that satisfies both parties, caused New Zealand and the United States submitted a request for official consultation with Indonesia through the WTO Dispute Settlement Body (hereinafter referred to as DSB) on May $8^{\text {th }} 2014$, which is known as DS No.477 (Indonesia-New Zealand) and DS No.478 (IndonesiaUS). This consultation was failed because of tejNew Zealand and the United States objections to the adoption of Indonesian policies that indicated contrary to Article XI Paragraph (1) GATT 1994 (Elimination of general quantitative restrictions) and Article 4 Paragraph (2) of the Agreement on Agriculture (Elimination of actions that should be changed is an ordinary customs duty). Indonesia also indicated violates the national treatment obligations under Article III Paragraph (4) GATT 1994 and the requirements for non-automatic import licensing based on Article 3 Paragraph (2) of The Import Licensing Agreement. In the consultation submission up to the appeal of this case, there were 14 third parties supported New Zealand and the US and had an interest in the subject matter, namely Argentina, Australia, Brazil, Canada, China, Japan, South Korea, European Union, Norway, Taiwan, Paraguay, India, Singapore, and Thailand.

${ }^{12}$ Kementrian Luar Negeri Republik Indonesia, Daftar Kerjasama Multilateral World Trade Organization (WTO), https://kemlu.go.id/portal/id/read/133/halaman_list_lainnya/ world-trade-organization-wto

${ }^{13}$ See LDC Identification Criteria \& Indicators in the United Nationsl Department of Economic and Social Affairs Economic Analysis, https://www.un.org/development/ desa/dpad/least-developed-country-category/ldc-criteria.html 
After the consultation failed, the US and New Zealand requested the Panel Agenda to DSB on 18 March 2015 and by the DSB, Panel established in The Centre William Rappard, Switzerland on 20 May 2015 with Mr. Harald Neple (Norway) as a Chairman. Several policies later became requests for submission of considerations by the United States and New Zealand including import licensing for horticultural products, animals and animal products and, some prohibition measures regarding import requirements on the inadequacy of domestic production to meet domestic needs. Upon the submission, Indonesia then submitted a defense based on Article XX of the GATT 1994, arguing that ${ }^{14}$ :

1. These actions are needed to protect the legal requirements as public morals (Article XX letter (a)),

2. Maintaining human life or health by ensuring food security/food safety (Article XX letter (b)),

3. Indonesia needs to ensure compliance with customs laws (Article $\mathrm{XX}(\mathrm{d}))$,

4. Indonesia also seeks to protect its actions based on Article XI paragraph 2 letter (c) (ii) of the 1994 GATT, which excludes the introduction of import restrictions designed to eliminate temporary surpluses such as domestic products.

The Panel found that all 18 (eighteen) actions in question are import restrictions or restrictions which indirectly have the effect of import restrictions within, therefore all those actions not in accordance with Article XI Paragraph (1) of GATT 1994. The Panel rejects Indonesia's defense based on Article XX of the GATT 1994, because Indonesia could not demonstrate that its actions are justified under these provisions, the 18 items of Indonesian policy which actions in question referred to as follows ${ }^{15}$ :

On the horticultural products:

1. Restrictions on the application window and validation period. The WTO assesses the existence of Article 13 Regulation Of The Minister Of Agriculture No. 86 of 2013 related to the archiving process and RIPH time restrictions are considered to be very detrimental to importers because the time period is very short, other than that this rule is considered not to count the length of time the goods are sent;

2. Periodic and permanent import terms;

3. Requirements $80 \%$ of the realization needs;

\footnotetext{
${ }^{14}$ World Trade Organization, DS 477: Indonesia - Importation of Horticultural Products, Animals and Animal Products, https://www.wto.org/english/tratop_e/dispu_e/ cases_e/ds477_e.htm

${ }^{15}$ Rachmi Hertanti, Megawati. Catatan Akhir \& Awal Tahun Indonesia For Global Justice: Catatan Dari Sengketa Investasi \& Perdagangan Internasional Dari Churchill Mining Hingga Kasus Impor di WTO di Era Proteksionism (Jakarta: Indonesia for Global Justice, 2017), 5-6.
} 
4. Requirements for the harvest period;

5. Storage ownership and capacity requirements. The WTO considers that the regulations made by Indonesia related to storage ownership and capacity requirements will be detrimental to importers and contrary to article XI paragraph (1) of the 1994 GATT because the spending costs will be greater, besides that storage ownership will have an impact on storage capacity restriction. While the process of storing imported goods can be done through a rental system;

6. Terms of use, sale and distribution of horticultural products;

7. Reference prices for chili and fresh red base for consumption;

8. Six months of harvest requirements;

9. Import licensing regimes for horticultural products.

On the animals and animal products:

10. Import restrictions on certain animals and animal products, except in emergencies;

11. Windows application limits and validity periods;

12. Periodic and permanent import terms;

13. Requirement of $80 \%$ of realized needs;

14. The use, sale and distribution of imported beef and offal;

15. Domestic purchasing requirements for beef;

16. Beef price reference;

17. Import licensing regimes for animals and animal products;

18. Adequacy of domestic production to meet domestic demand.

In the Panel Report, circulated to Members of the World Trade Organization (WTO) on 22 December 2016, the Panel made the following findings that the 18 items of Indonesian policy which actions in question are not in accordance with the applicable WTO regulations, namely ${ }^{16}$ :

a) The 1-18 policy: not in accordance with Article XXI (1) GATT 1994;

b) The 1 - 3 policy: not in accordance with Article XXII (d) GATT 1994;

c) The 4 policy: not in accordance with Article XXII (b) GATT 1994;

d) The 5-6 policy: incompatible with Article XXII (a) (b) (c) GATT 1994;

e) The 7-8 policy: not in accordance with Article XXII(b) GATT 1994;

f) The 9-12 policy: not in accordance with Article XXII (a) (b) (d) GATT 1994;

g) The 6, 14 and 15 policies: inconsistent with Article II (4) GATT 1994;

h) The 1-11 policy: not in accordance with Article 3.2 of the Import License Agreement.

16 World Trade Organization, Indonesia - Importation of Horticultural Products, Animals and Animal Products, https://www.wto.org/english/tratop_e/dispu_e/cases_e/ ds478_e.htm 
Based on the results of the WTO DSB Panel report, there are a number of Indonesian laws and regulations that are declared or judged to be inconsistent with the existing WTO rules, such as ${ }^{17}$ :

1. Law. Number: 19 year of 2013 concerning Farmer Protection and Empowerment.

2. Law Number: 18 year of 2012 Concerning Food.

3. Law Number: 13 year of 2010 Concerning Horticulture.

4. Regulation of The Minister of Agriculture Number: 86/PERMENTAN/ OT.140 /8/2013 concerning the Import Recommendation of Horticultural Products.

5. Regulation of The Minister of Agriculture Number: 139/ PERMENTAN / Pd.410/12/2014 concerning Import of Carcasses, Meats and/or Processed Products into the Territory of the Republic of Indonesia.

6. Regulation of The Minister of Agriculture Number: 02/PERMENTAN/ PD.410/1/2015 concerning Amendment to PERMENTAN No. 139/PERMENTAN/PD.410/12/2014 concerning Import of Carcasses, Meats and/ or Processed Products into the Territory of the Republic of Indonesia.

7. Regulation of the Minister of Trade No.16/M-DAG/PER/4/2013 concerning Provisions on the Import of Horticultural Products.

8. Regulation of the Minister of Trade No.47/M-DAG/PER/8/2013 concerning amendment to Regulation of the Minister of Trade No.16/M-DAG/PER/4/2013 concerning Provisions on the Import of Horticultural Products.

9. Regulation of the Minister of Trade No.46/M-DAG/PER/8/2013 concerning Provisions on the Import and Export of Animals and Animal Products.

10. Regulation of the Minister of Trade No.57/M-DAG/PER/9/2013 concerning Amendment to the regulation of the Minister of Trade No.46/M-DAG/PER/8/2013 concerning the provisions on the import and export of animals and animal products.

The WTO DSB panel stated that Indonesia had acted inconsistently with Article 11 paragraph (1) of the 1994 GATT, thereby eliminating or harming the benefits owned by the United States and New Zealand from the GATT rules. The Panel has also issued a recommendation for Indonesia to immediately adjust some of its domestic policies to the 1994 GATT rules. Based on this decision, Indonesia On February 17, 2017, informed the DSB of its decision to appeal to the DSB on legal issues and certain legal interpretations in the panel report. In the later time on November 9, 2017 The Appellate Body reported the results of its examination to WTO members, which was followed by a meeting on November 22, 2017. The DSB then 
adopted the Appellate Body report and Panel Report, which subsequently decided to win New Zealand and the United States over quantitative restrictions on imports of horticultural products, animals and animal products made by Indonesia.

As a sovereign country Indonesia is free in determining its national policies and foreign trade, however as a member of the WTO, besides being given the freedom to create and apply its own national legal procedures, Indonesia must also automatically have to be consistent and binding with the provisions of the WTO. Based on The Most Favoured Nation (MFN) principle on Article I of the GATT, a trade policy must be implemented on a non-discriminatory basis. All member countries are bound to give other countries the same treatment in the implementation and import and export policies as well as those involving other costs. The same treatment must be carried out immediately and without conditions (immediately and unconditionally) on products originating from or submitted to all GATT members ${ }^{18}$. Besides the MFN Principle, the National Treatment principle on Article III GATT also prohibits discriminatory regulations as a tool to protect the product domestic, including taxation and other levies. This principle also applies to all legislation, legal arrangements, and requirements that can affect the sale, purchase, distribution, or use of products on the domestic market and provide protection against protectionism as administrative or legislative measures or policies ${ }^{19}$.

Based on the two non-discriminatory principles (The Most Favoured Nation and the National Treatment principle) above, within DSB decision on November 22, 2017 whose win New Zealand and the United States over Indonesia's quantitative restrictions on imports of horticultural products, animals and animal products, Indonesia must immediately comply and adjust its national policies to the GATT rules within the stipulated period. If it is not Indonesia must provide compensation to New Zealand and the United States, the amount of which is mutually agreed upon. If an agreement is still not reached on the form or amount of compensation, then New Zealand and the United States can request the WTO DSB to propose retaliation or countermeasures against Indonesia. WTO DSB decision which consisting rulings and recommendations are legally binding and raise an obligation to the parties in the dispute based on international law ${ }^{20}$.

Indonesia's defeat, in this case, will have an impact on its national food policy and the alignment of Indonesia's food policy with the 1994 GATT

18 Huala Adolf. Hukum Perdagangan Internasional. (Jakarta: Raja Grafindo Persada, 2005), 108.

19 Nurhani Fithriah, "Penerapan Prinsip Non-Diskriminatif dan National Treatment Oleh Indonesia Dalam Rangka MEA Berdasarkan Undang-Undang Nomor 25 Tahun 2007 Tentang Penanaman Modal," University of Bengkulu Law Jurnal 1, no. 1 (2017): 81-82.

20 John H. Jackson, "International Status of WTO Dispute Settlement Reports: Obligation to comply or Option to Buy Out?," American Journal of International Law 98, No.1 (2004):109. 
rules will directly contradict the spirit of food sovereignty which is currently being fought by Indonesia. On the appeal decision, on 15 December 2017, Indonesia confirmed the DSB (Dispute Settlement Body) that a reasonable time was needed to comply with the DSB recommendations and regulations bearing in mind the 45 (forty-five) days deadline stipulated in Article 21 paragraph (3) letter $b$ Understanding on Rules and The Governing the Settlement of Disputes (DSU) procedure end on 6 January 2018. Based on considerations at the Ministerial Conference in Buenos Aires and the closing of the WTO year-end, On 11 January 2018, Indonesia, New Zealand, and the United States notified the DSB that to provide sufficient time for them to discuss the mutually agreed period and they have agreed that the deadline for arbitration is based on Article 21 paragraph (3) letter c of the DSU21.

In recent development indicates that Indonesia has issued the Ministry of Agriculture Regulation No. 2 of 2020, which amends the previous regulation No. 39 of 2019 concerning Recommendations for Importation of Horticultural Products and to ensure the harmonization of the amended regulation, Indonesia is currently in the process of amending the Ministry of Trade Regulation No. 44 of 2019.22

\subsection{Indonesia's Opportunities in Creating Food Sovereignty after WTO DS 477 and DS 478 Cases}

Before discussing Indonesia's possibilities to achieve food sovereignty, its concept seems to need to be clarified. The term food sovereignty upcoming first in April 1996, on the Second International Conference in Tlaxcala, Mexico, by the activist group La Via Campesina and subsequently brought at the civil society conference held in conjunction with the World Food Summit in Rome in $1996 .{ }^{23}$ The term food sovereignty was defined as follow: 24

Food Security cannot be achieved without taking full account of those who produce food. .... Food sovereignty is the right of each nation to maintain and develop its own capacity to produce ...... We have the right to produce our own food in our own territory. Food sovereignty is a pre-condition to genuine food security.

The position of the organization and statement presented food sovereignty as stated is an anti-colonial critique of the foreign domination of states by the

${ }^{21}$ See Article 21 Paragraph (3) letter c of the GATT Dispute Settlement Understanding.

22 World Trade Organization, Status Report Regarding Implementation of the DSB Recommendations and Rulings by Indonesia- Addendum, No. WT/DS477/21/Add.14 and No.WT/DS478/22/Add.14, Indonesia - Importation of Horticultural Products, Animals and Animal Products, dated 23 March 2020.

23 Gbadebo Odularu, Emmanuel Tambi, Adebayo Aromolaran, Bola Oyeleye. Food Sovereignty and Food Security: Where does Africa Stand?, (Accra, Ghana: Forum for Agricultural Research in Africa/FARA, 2014), 10.

${ }^{24}$ Marc Edelman, Food Sovereignty: Forgotten Genealogies and Future Regulatory Challenges, The Journal of Peasant Studies 41, no.6 (2014): 959-978 
international trade rules of the World Trade Organisation WTO as well as the neoliberal credit conditions imposed by the World Bank and the International Monetary Fund. ${ }^{25}$

Towards A Food Sovereignty Action Agenda from the Nyéléni Forum for Food Sovereignty, 23rd - 27th February 2007, Sélingue, Mali, described Food Sovereignty as follows:

- The right of individuals, peoples, communities and countries to define their own agricultural, labour, fishing, food, land and water management policies, which are ecologically, socially, economically and culturally appropriate to their unique circumstances;

- The true Right to Food and to produce food, which means that everyone has the right to safe, nutritious and culturally appropriate food and to food-producing resources and the ability to sustain themselves and their societies;

- The right to protect and regulate domestic production and trade and prevent the dumping of food products and unnecessary food aid in domestic markets;

- Self-reliance in food to the extent desired;

- Managing the use of, the rights to and control over natural resources - land, waters, seeds, livestock breeds and wider agricultural biodiversity unrestricted by intellectual property rights and without GMOs;

- Based on and supportive of ecologically sustainable production and harvesting, principally agroecological production and artisanal fisheries $^{26}$.

In the Nyéléni Declaration, those descriptions above become the concept in the establishment of six pillars for food sovereignty, that Focuses on food for people, Values food providers, Localizes food systems, Puts control locally, Builds knowledge and skills, and food sovereignty that Works with nature. ${ }^{27}$ In furtherance of food sovereignty, various social movements, NGOs, including Via Campesina coalesced and become a central point of the food sovereignty movement which formed as the International Planning Committee for Food Sovereignty.

Seeking the possibilities in creating food sovereignty based on the WTO DS 477 and DS 478 case, Indonesia should be able to predict the legal standing and the legal possibilities that might occur, so that Indonesia can find other alternatives over the existing WTO mechanism. This is based on the consideration that in the development of the case can be seen that none

${ }^{25}$ Food Sovereignty Report Topic, https://www.globalagriculture.org/report-topics/food sovereignty.html

26 Towards A Food Sovereignty Action Agenda from the Nyéléni Forum for Food Sovereignty, 23rd - 27th February 2007, Sélingué, Mali, https://www.nyeleni.org/IMG $\angle$ pdf/TOWARDS_A_FOOD_SOVEREIGNTY_ACTION_AGENDAII.pdf

27 Declaration of Nyéléni 27 February 2007 Nyéléni Village, Sélingué, Mali, https://nyeleni.org/IMG/pdf/DeclNyeleni-en.pdf 
of the 18 (eighteen) actions that were questioned by the United States and New Zealand confirmed or justified Indonesia's actions so that the consequences of Indonesia's legal position in winning the case were very low, and as previously predicted that the results of the Panel Board decision on 22 December 2016 and the decision of the Appellate Body on 22 November 2017 have ruled that Indonesia was defeated by the lawsuit of New Zealand and the United States.

From the development of the WTO DS 477 and DS 478 cases during the panel and appeal, Indonesia has made efforts to maintain the policy that has been made by arguing that Indonesia is a developing country that is currently trying to develop agriculture and create food security in their country, Indonesia has also proposed an evidence to counter US and New Zealand suspicions that Indonesian import regulations have not limited the number of horticultural imports, animals and animal products from New Zealand and America. In this cases, Indonesia was arguing has never restricted imports of agricultural products, animals and animal products from New Zealand, US and the other country as long as it does not conflict with the provisions of the Minister of Trade Regulation No.16/MDAG/PER/4/2013 concerning Provisions on the Import of Horticultural Products and Regulation of the Minister of Trade No.46/MDAG/PER/8/2013 concerning Provisions on the Import and Export of Animals and Animal Products. Arguments submitted by Indonesia which bringing the global issue of food sovereignty have not been so convincing both the Panel and the Appellate Body as they finally decided in favour of New Zealand and the United States.

On one hand, if Indonesia enforces the WTO DS 477 and DS 478 decisions, Indonesia must liberalize provisions on the import of horticulture, animals, and animal products. On the other hand, if it will be implemented without restrictions, it can directly harm small-scale farmers and breeders, farmers' exchange rates will decline because they have difficulty competing and of course the welfare of the wider community will be at stake. Currently, because there is an agreement with the United States that based on the provisions of article 21 paragraph (3) letter c of the DSU, Indonesia has a grace period to make adjustments to its horticultural, animal and animal product trading policies. Based on the agreement that the first phase of adjusting Indonesia's policy is carried out no later than 22 July 2018 and for the second phase carried out on 22 June 201928.

Although bilateral consultations were carried out and adjustment steps have also been taken by the Government of Indonesia, in a stakeholder consultation that took place on 27 July 2018 in Geneva, the

28 Detik, Begini Kronologi Gugatan Trump Rp 5 T ke RI, https://finance.detik.com/ berita-ekonomi-bisnis/d-4155699/begini-kronologi-gugatan-trump-rp-5-t-ke-ri 
United States stated that Indonesia had not made enough adjustments. The US then submitted retaliation pursuant to Article 22 Paragraph (2) of the WTO Dispute Settlement Understanding to secure its right to delay granting tariff concessions to Indonesia if Indonesia truly fails to implement the WTO Dispute Settlement Agency's recommendations ${ }^{29}$. The value of retaliation proposed by the United States is USD 350 million or equivalent to Rp 5 trillion, while New Zealand calculates NZD 1 billion or equivalent to Rp 9 trillion which will be imposed annually until Indonesia can adjust its actions to WTO provisions. To implement the WTO decision, in 2020 Indonesia will push for changes to 4 Laws which include Law No.18 of 2009 concerning Animal Husbandry and Animal Health, Law No.13 of 2010 concerning Horticulture, Law No.18 of 2012 concerning Food, and Law No. 19 of 2013 concerning Protection and Empowerment of Farmers ${ }^{30}$.

However, to be able to discuss bilaterally what might be done to avoid retaliation while reducing the demands of the plaintiffs, Indonesia also needs to try to propose a Mutually Agreed Solution (MAS) strategy while improving the provisions on the import of horticulture and animal product imports and of course it needs to be accompanied by other concessions in the food sector or with other product concessions. Reflecting on the results of the Appellate Body's decision on the WTO DS 477 and 478 cases, we can see that the position of developing countries like Indonesia in defending themselves against the effects of free trade is very vulnerable. It is quite obvious that economic and social problems are still become the greatest challenge in realizing equality and prosperity in developing countries.

Before the WTO DS 477 and DS 478 case, Indonesia also has experience in a similar case to the United States namely the WTO DS 406.31 Indonesia believes that the US issued a policy that harms Indonesia by issuing policies that prohibit the circulation of aromatic cigarettes, including clove cigarettes, but excluding menthol-flavored cigarettes. In this regard, Indonesia claims that the US has doing discrimination against trade and violates WTO regulations. Indonesia won the case, but the United States did not want to change its tobacco law, so Indonesia asked for authorization from the WTO Arbitration to conduct a retaliation of US \$ 55 million ${ }^{32}$.

From this experience also Indonesia should have learned that the WTO mechanism has weaknesses where a lengthy and costly process is

${ }^{29}$ Ibid.

${ }^{30}$ Kumparan, RI Terancam Sanksi dari WTO, Mentan Dorong Revisi 4 Undang-Undang, https://kumparan.com/kumparanbisnis/ri-terancam-sanksi-dari-wto-mentan-dorongrevisi-4-undang-undang-1sHGaNHVPpy

31 World Trade Organization, Dispute Settlement Body, DS406: United States Measures Affecting the Production and Sale of Clove Cigarettes

${ }^{32}$ Kompas, RI dan AS Akhiri Sengketa Dagang Rokok Kretek, http://bisniskeuangan. kompas.com/read/2014/10/07/154801926/RI.dan.AS.Akhiri.Sengketa.Dagang.Rokok.Kre $\underline{\text { tek }}$ 
needed to file a lawsuit until there is a final decision from the WTO panel board, on the other hand, developed countries that have a strong economy such as America often do not respond to consultations in the mechanism, often forgetting their obligations and always busy demanding the right to gain political influence and bargaining position. So that a bilateral mechanism with a compromise between the two parties to the dispute is better used, by prioritizing diplomacy and bargaining positions that give Indonesia time to think and improve its policies and for that Indonesia needs to strengthen its diplomatic position by asking for consideration and involving experts who understand WTO rules, especially those who concerning the Agreement on Agriculture (AoA), The Import Licensing Agreement, GATT 1994 and other related regulations.

The WTO Appellate Body decisions on DS 477 and DS 478 cases do not fully lose Indonesia's expectation to improving its multilateral trading conditions as the market for national agricultural, animal, and animal products is still available. The $11^{\text {th }}$ Ministerial Meeting in Buenos Aires on December 10-13, 2017 was a forum to discuss the issue concerned. During the meeting, Indonesia raised some issues including the Public Stockholding for Food Security Purposes (PSH) and Special Safeguard Mechanism (SSM), both of which were also championed by G-33 member countries under Indonesia's coordinator. ${ }^{33}$

The meeting was also a momentum to discuss agricultural issues again, in accordance with the mandate of the Doha Development Agenda to improve Indonesia's bargaining position as one of the developing countries in international trade traffic. One of the outcomes of the G-33 meeting is Encouraging global agricultural reform and creating a strong, fair, and legal multilateral trade framework through special and differential treatment based on the effective application. Furthermore, as a suggestion at this point, it is more important for Indonesia to create a national food security design pattern to compete at the international level and also able to create sustainability and food sovereignty in its own country. Food sovereignty is a basis for genuine food security, but in terms of the corporate food regime, food security achieved through trade rather than through a strategy of selfsufficiency. La Via Campesina emphasized that a farmer-based production system is important so that food can be produced in a god variety of ways, and food sovereignty of the world community can be guaranteed. ${ }^{34}$

According to Windfuhr and Jonsen, "While food security is more of technical concept, and the right to food a legal one, food sovereignty is

33 Kadata, Indonesia Perjuangkan Isu Ketahanan Pangan di WTO, https:// katadata.co.id/berita/2017/12/13/indonesia-perjuangkan-isu-ketahanan-pangan-di-wto

${ }^{34}$ Gbadebo Odularu, Emmanuel Tambi, Adebayo Aromolaran, Bola Oyeleye, OP.Cit.; 12. 
essentially a political concept." 35 In 1996, as a policy framework and discourse, food sovereignty through the Agreement on Agriculture (AoA) firstly emerged in response to the inclusion of agriculture within the world trading system. ${ }^{36}$ Food sovereignty encourages the formulation of trade policies and practices that serve the people's right to sustainable, healthy, and ecologically sustainable production, it means that food sovereignty does not negate the trade. Food sovereignty is stated as a prerequisite for the existence of food security and depends on those who produce food and care for the sustainability of the natural environment. ${ }^{37}$ Food sovereignty and food security having conceptually can be distinguished one and each other. One hand, food sovereignty enables a country to produce the food as much as it needs while on the other hand, food security allows a country to either produce or import food as needed. The huge import of commodities mostly always hurts the farmers. ${ }^{38}$

The achievement of food sovereignty will be difficult to achieve, because the mechanism of trade liberalization in the food sector, requires the government to open the faucet wide import of food products. This resulted will weakening the position of traditional farmers and make the disruption of domestic food production, and this situation also will lead to greater dependence on imported food products. ${ }^{39}$ Currently, there is no other choice for Indonesia other than improving horticultural, animal and animal product trade policies as mandated by the WTO while continuing to fight for food sovereignty, and strengthening national strategies to create food security more important for Indonesia to be better prepared to face the development of trade liberalization in the future. In addition to trade liberalization, there are other key elements such as technical and financial capacity, education, and infrastructure to achieve food security goals. However, without reducing the role of trade in international relations, as stated by the UN Millennium Project that trade openness can be a powerful driver of economic growth, which is indispensable for reducing poverty and encouraging development ${ }^{40}$.

35 Richard Lee, "Food Security and Food Sovereignty," Centre for Rural Economy Discussion Paper Series No. 11 (2007): 5.

36 Ibid.

${ }^{37}$ E O H Soetoto, The impact of Indonesia's Food Law Reform on the Concept of Food Sovereignty in Indonesia, IOP Conf. Series: Earth and Environmental Science 131 (2018):2

38 Statement by Dwi Andreas Santosa, a professor at the Bogor Agricultural Institute in Bogor, Indonesia. VOA Learning English, Indonesia's Goal of Food Sovereignty Remains a Work in Progress, https://learningenglish.voanews.com/a/indonesia-s-goal-of-foodsovereignty-remains-a-work-in-progress/4652007.html

39 HS. Tisnanta, Ade Arif Firmansyah , and Malicia Evendia, "Reflection On Indonesia's Food Regulation: The Dilemma Between Trade Liberalization, Food Sovereignty and Protection of Traditional Farmers," International Journal of Business, Economics and Law 6, no.4 (2015): 164.

40 Ernesto Zedillo, Patrick Messerlin, and Julia Nielson. Trade for Development: Achieving the Millennium Development Goals (London: Earthscan, 2005), 257. 
Intensification and extensification policies in products and agricultural land seems to need to be adopted. Agricultural intensification is carried out by utilizing appropriate technology suitable for topography and geography. This should be followed by the adaptation of environmental friendly-modern technologies of agriculture and livestock to ensure the highvalue commodities to be able to compete in local and international markets. In increasing the quality of animal products, there is a need of improving the quality of seeds and feed, maintenance and health patterns, production and distribution management, and controlling the availability of supply needs. Next, eradication and disease controls need to be taken into careful consideration. The quality and health assurance of the products must be guaranteed. This requires a synergy between departments and offices responsible for animal husbandry, health, and agricultural affairs.

The extensification policies are to be carried out by expanding land use, opening new land areas, and implementing agrarian reform. ${ }^{41}$ Agrarian reform should be transformed into a guarantee of certainty of land ownership, preventing impartiality in the consolidation of agricultural land, regulating and controlling of agricultural land conversion. It needs to empower landless poor farmers who tend to shift the agricultural life in the rural economy with agriculture life owned by the capital owner. Spatial arrangements that guarantee the availability of water, agricultural land, and conservation are also needed to maintain sustainability and prevent environmental damage. ${ }^{42}$

Another issue in developing agriculture and food security is the effort to combat food cartels that have weakened people's economy through monopolistic practices and approaching power circles. Lastly, the government should pay concern on the creation and implementation of various international trade regulations that may potentially invade Indonesia with dumping practices, subsidies, incentives, and protection of their trade products through strong diplomacy and advocacy.

\section{Conclusion}

Based on the discussion that has been presented above, this article concludes as follows:

1) Indonesia's position in the case of DS 477 and DS 478 was weak. Despite Indonesia was defeated in those cases, the opportunities for Indonesian agricultural products to be internationally marketed are still available. The bilateral arrangement referring to Article 21 (3) (c)

${ }^{41}$ As mandated by the Decree of the People's Consultative Assembly of the Republic of Indonesia Number IX/MPR-RI/2001 concerning Agrarian Reform and Natural Resource Management

42 As stipulated in Law No.26 year of 2007 concerning Spatial Planning and Law No.32 year of 2009 concerning Environmental Protection and Management. 
of DSU enables Indonesia to discuss bilaterally with New Zealand and the US regarding upcoming legitimate measures to be adopted.

2) Reflecting on the results of WTO DS 477 and DS 478 cases, Indonesia should propose a Mutually Agreed Solution (MAS) and improving the provisions on horticulture imports and imports of animal products. Indonesia should also carry out intensification and extensification policy. Besides, a serious effort to eliminate food cartels needs to be conducted. Lastly, Indonesia should pay concern on the creation and implementation of various international trade regulations that may potentially invade Indonesia with dumping practices, subsidies, incentives, and protection of their trade products through strong diplomacy and advocacy.

\section{Book}

\section{BIBLIOGRAPHY}

Zedillo, Ernesto, Patrick Messerlin, and Julia Nielson. Trade for Development: Achieving the Millennium Development Goals. London: Earthscan, 2005.

Adolf, Huala. Hukum Perdagangan Internasional. Jakarta: Raja Grafindo Persada, 2005.

Friedman, Thomas L. The Lexus and the Olive Tree: Understanding Globalization, 2 $2^{\text {nd }}$ edition. New York: First Anchor Books, 2000.

Tambi, Emmanuel, Adebayo Aromolaran, Gbadebo Odularu, and Boya Oyeleye. Food Sovereignty and Food Security: Where Does Africa Stand? Accra, Ghana: Forum for Agricultural Research in Africa (FARA), 2014.

Van den Bossche, Peter. The Law And Policy of the World Trade Organization: Text, Cases, and Materials, $2^{\text {nd }}$ edition. New York: Cambridge University Press, 2008.

Winiarko, Budi. Globalisasi Pangan "Masih adalah Peluang bagi Pertanian Indonesia" dalam Revitalisasi Pertanian dan Dialog Peradaban. Jakarta : Kompas, 2006.

\section{Journal Article}

Kadir, M. Ya'kub Aiyub. "The World Trade Organization (WTO) Free Trade Within Fair Trade Challenges." Mimbar Hukum 26, no.1 (2014): 125136. https://doi.org/10.22146/jmh.16058

Edelman, Marc. Food Sovereignty: Forgotten Genealogies and Future Regulatory Challenges. The Journal of Peasant Studies 41, no.6 (2014): 959-978. https://doi.org/10.1080/03066150.2013.876998

Fithriah, Nurhani "Penerapan Prinsip Non-Diskriminatif dan National Treatment Oleh Indonesia Dalam Rangka MEA Berdasarkan UndangUndang Nomor 25 Tahun 2007 Tentang Penanaman Modal." University of Bengkulu Law Jurnal 1, no. 1 (2017): 80-90. https://doi.org/10.33369/ubelaj.2.1.80-90 
Jackson, John H. "International Status of WTO Dispute Settlement Reports: Obligation to Comply or Option to Buy Out?." American Journal of International Law 98, no.1 (2004):109-125. https: / / doi.org/10.2307/3139260

Lee, Richard. "Food Security and Food Sovereignty." Centre for Rural Economy Discussion Paper Series no. 11 (2007): 1-16.

Lee, Yong-Shik. "International Trade Law Post Neoliberalism." Buffalo Law Review 68 no.2 (2020): 413-478.

Soetoto, E.O.H. "The Impact of Indonesia's Food Law Reform on the Concept of Food Sovereignty in Indonesia." IOP Conf. Series: Earth and Environmental Science 131 (2018):1-5. https://doi.org/10.1088/1755$1315 / 131 / 1 / 012026$

Tisnanta, HS, Ade Arif Firmansyah, and Malicia Evendia. "Reflection on Indonesia's Food Regulation: The Dilemma Between Trade Liberalization, Food Sovereignty and Protection of Traditional Farmers." International Journal of Business, Economics and Law, 6, no.4 (2015):158-164.

Wolfe, Robert. "Sprinting during a Marathon: Why the WTO Ministerial Failed in July 2008." Journal of World Trade 44, no. 1 (2010): 81-126.

\section{Law and Regulation of the Republic of Indonesia}

The 1945 Constitution of the Republic of Indonesia.

Decree of the People's Consultative Assembly of the Republic of Indonesia Number IX/MPR-RI/2001 concerning Agrarian Reform and Natural Resource Management.

Law No.26 year of 2007 concerning Spatial Planning and Law No.32 year of 2009 concerning Environmental Protection and Management.

Law No.41 of 2009 concerning the Protection of Sustainable Agricultural Land

Law No.13 of 2010 concerning Horticulture

Law No.18 of 2012 concerning Food

Minister of Agriculture Minister No.86/Permentan/OT.140/8/2013 concerning Horticultural Product Import Recommendations

Minister of Agriculture Regulation No. 39/2019 concerning Horticultural Product Import Recommendations

Minister of Agriculture Regulation No. 2 of 2020 concerning Horticultural Product Import Recommendations

Minister of Trade Regulation No. 44 of 2019 concerning Provisions on the Import of Horticultural Products

\section{Other Documents}

Declaration of Nyéléni, Nyéléni Village, Sélingué, Mali, 27 February 2007 https://nyeleni.org/IMG/pdf/DeclNyeleni-en.pdf

Hertanti, Rachmi and Megawati. Catatan Akhir \& Awal Tahun Indonesia For Global Justice: Catatan Dari Sengketa Investasi \& Perdagangan Internasional-Dari Churchill Mining Hingga Kasus Impor di WTO di Era Proteksionism. Jakarta: Indonesia for Global Justice, 2017. 
World Trade Organization Dispute Settlement, Understanding on Rules and Procedures Governing the Settlement of Disputes.

World Trade Organization, Status Report Regarding Implementation of the DSB Recommendations and Rulings by Indonesia- Addendum, No. WT/DS477/21/Add.14 and No.WT/DS478/22/Add.14, Indonesia Importation of Horticultural Products, Animals and Animal Products, dated 23 March 2020.

\section{Case Law}

World Trade Organization, Dispute Settlement Body, DS406: United States - Measures Affecting the Production and Sale of Clove Cigarettes

World Trade Organization, Dispute Settlement Body, DS477 and DS478: Indonesia - Importation of Horticultural Products, Animals and Animal Products

\section{Website Content}

Detik. Begini Kronologi Gugatan Trump Rp 5 T ke RI. https://finance.detik. com/berita-ekonomi-bisnis/d-4155699/begini-kronologi-gugatantrump-rp-5-t-ke-ri

Global Agriculture. Food Sovereignty. https://www.globalagriculture.org/report-topics/food sovereignty.html

Kadata. Indonesia Perjuangkan Isu Ketahanan Pangan di WTO. https://katadata.co.id/berita/2017/ 12/13/indonesia-perjuangkanisu-ketahanan-pangan-di-wto

Kementrian Luar Negeri Republik Indonesia. Daftar Kerjasama Multilateral World Trade Organization (WTO). https://kemlu.go.id/portal/ $\mathrm{id} / \mathrm{read} / 133 /$ halaman_list_lainnya/world-trade-organization-wto

Kompas. RI dan AS Akhiri Sengketa Dagang Rokok Kretek. http:/ / bisniskeuangan.kompas.com/read/2014/10/07/154801926/ RI.dan.AS.Akhiri.Sengketa.Dagang.Rokok.Kretek

Kumparan. RI Terancam Sanksi dari WTO, Mentan Dorong Revisi 4 Undang-Undang. $\quad$ https://kumparan.com/kumparanbisnis/riterancam-sanksi -dari-wto-mentan-dorong-revisi-4-undang-undang1sHGaNHVPpy

Liputan 6, Menko Darmin Ungkap Sebab RI Harus Impor Beras. http://www. bisnis.liputan6.com/read /3227216/menko-darminungkap-sebab-ri-harus-impor-beras

Towards A Food Sovereignty Action Agenda from the Nyéléni Forum for Food Sovereignty, 23rd - 27th February 2007, Sélingué, Mali, https://www.nyeleni.org/IMG/pdf/TOWARDS_A_FOOD_SOVEREIGN TY_ACTION_AGENDAII.pdf

United Nations Department of Economic and Social Affairs. Least Developed Country Category. https://www.un.org/development/desa/dpad /least-developed-country-category/ldc-criteria.html

United Nations Department of Economic and Social Affairs Economic Analysis. LDC Identification Criteria \& Indicators. 
https://www.un.org/ development/desa/dpad/least-developedcountry-category/ldc-criteria.html

VOA Learning English. Indonesia's Goal of Food Sovereignty Remains a Work in Progress. https://learningenglish.voanews.com/a/indonesias-goal-of-food-sovereignty-remains-a-work-in-progress/4652007.html

World Trade Organization. DS 477: Indonesia - Importation of Horticultural .Products, Animals and Animal Products. https://www.wto.org/english/tratop_e/dispu_e/cases_e/ds477_e.htm World Trade Organization. Indonesia - Importation of Horticultural Products, Animals and Animal Products. https://www.wto.org/english/ tratop_e/dispu_e/cases_e/ ds478_e.htm 